\title{
Emosjonsregulering og motivasjon hos barn med AD/HD
}

\begin{abstract}
Sammendrag
Bakgrunn. Svikt i kognitive kontrollfunksjoner er lenge blitt sett på som hovedproblemet i utvikling av attention deficit/hyperactivity disorder (AD/HD). I en nyere modell fremheves imidlertid betydningen av emosjonelle og motivasjonelle problemer hos personer med $A D / H D$. Vi gjennomgår bakgrunnen for denne modellen, som kan vise seg å ha viktige implikasjoner for klinisk praksis.
\end{abstract}

Materiale og metode. Denne oversikten er skrevet etter et ikke-systematisk litteratursøk i PubMed. Artiklene er valgt ut på bakgrunn av forfatternes erfaring innen feltet.

Resultater. Det er gjort få studier på dette området, som nå vies økende forskningsaktivitet. Personer med $\mathrm{AD} / \mathrm{HD}$ reagerer annerledes enn kontrollpersoner på oppgaver som inkluderer belønning eller stresser kapasiteten til å regulere følelser. Avvikende signaler ved unders $ø$ kelse med elektroencefalografi (EEG) og anatomisk og funksjonell magnetisk resonanstomografi (fMR) reflekterer problemer med emosjonsreguleringen hos pasienter med AD/HD.

Fortolkning. Nevrobiologisk forskning støtter modellen som inkluderer emosjonelle og motivasjonelle problemer i utviklingen av AD/HD. Økt kunnskap om slike problemer kan på sikt gi bedre behandling av pasientene gjennom utvikling av mer individuelt tilpassede terapiformer.

\author{
Marie Farstad Høvik \\ Institutt for klinisk medisin \\ Det medisinsk-odontologiske fakultet \\ Universitetet i Bergen \\ Kerstin J. Plessen \\ kerstin.plessen@uib.no \\ Institutt for biologisk og medisinsk psykologi \\ Det psykologiske fakultetet \\ Universitetet i Bergen \\ Jonas Lies vei 91 \\ 5009 Bergen \\ og \\ Institutt for klinisk medisin \\ Det medisinsk-odontologiske fakultet \\ Universitetet i Bergen \\ og \\ Psykiatrisk divisjon \\ Haukeland universitetssykehus
}

Han er ingen enkel pasient, denne gutten på ti år som ikke vil sitte i ro og høre på legen som andre barn gjør. Han har snudd opp ned på venterommet på fem minutter. På kontoret tar han på absolutt alt, han pumper opp blodtrykksmansjetten til den nesten sprekker. Han har dårlige resultater på skolen, bekymrede og slitne foreldre, få venner, indre uro... Han gjør så godt han kan - hvorfor får han det ikke til?

Tidligere handlet den fremtredende teorien om årsaken til symptomer på attention deficit/hyperactivity disorder (AD/HD) først og fremst om kognitive kontrollfunksjoner. En nyere modell for tilstanden inkluderer også emosjonelle og motivasjonelle faktorer (1). Kan mange av de problemene AD/HD-pasientene har skyldes at de ikke klarer å regulere sine egne følelser, som ledd i generelle problemer med å regulere seg selv (2)? Vi vil her presentere sentrale deler av den begrensede forskningen som foreligger på dette feltet - ved en gjennomgang av kliniske og genetiske aspekter, endofenotyper og miljø med henblikk på emosjonsregulering og motivasjon hos personer med AD/HD.

I artikkelen har vi lagt hovedvekt på endofenotyper, som vi vil drøfte innenfor nevropsykologi, hjerneavbildning og elektrofysiologi. I psykiatrien er en endofenotype en målbar egenskap i hjernen eller ved atferden som er et bindeledd mellom genotype og fenotype. Endofenotyper er arvelige, uavhengige av nåværende alvorlighetsgrad av sykdommen og til stede hos ikke-affiserte familiemedlemmer i høyere grad enn i normalbefolkningen (3). Avslutningsvis vil vi kort drøfte hvilken betydning endofenotypene har når det gjelder forebygging og behandling av $\mathrm{AD} / \mathrm{HD}$.

\section{Materiale og metode}

Artikkelen er skrevet på bakgrunn av et ikke-systematisk litteratursøk i PubMed. Det er gjort et artikkelutvalg ut fra forfatternes erfaring innen feltet.

\section{Kliniske symptomer}

$\mathrm{AD} / \mathrm{HD}$ har en prevalens på 5,3\% i barneog ungdomsbefolkningen på verdensbasis (4) og er dermed en av de hyppigste psykiatriske lidelsene hos barn. Hovedsymptomene er oppmerksomhetsvansker, hyperaktivitet og impulsivitet (5).

Pasientene har problemer med å regulere tanker, følelser og atferd, noe som fører til de typiske symptomene (6). Selvregulering innebærer bruk av mentale kontrollfunksjoner som tillater oss å regulere vår atferd over tid for å nå våre mål. Kognitive kontrollfunksjoner omfatter hemming av automatiske responser, arbeidsminne og evne til planlegging. Emosjonelle/motivasjonelle kontrollfunksjoner inkluderer regulering av emosjoner og impulsivitet og er forbundet med belønningssystemer og motivasjon. Innen $\mathrm{AD} /$ HD-forskningen har man lenge lagt vekt på problemer med kognitive kontrollfunksjoner, ut fra at det er disse problemene som gir symptomer på sykdommen, noe som stemmer overens med dagens diagnostiske kriterier. Den nyere modellen (dual pathway-modellen) omfatter både kognitive kontrollvansker og motivasjonelle faktorer som parallelle årsaker til utvikling av AD/HDsymptomer (7). Dette innebærer at dagens diagnosekriterier neglisjerer noen områder som barn med sykdommen strever med (fig 1).

Mange barn med AD/HD har problemer med emosjonsreguleringen $(8,9)$. Disse pro-

\section{Hovedbudskap}

- Personer med AD/HD har både emosjonelle, motivasjonelle og kognitive problemer

- Måling av endofenotyper tyder på at personer med AD/HD har avvik i motivasjons- og emosjonsreguleringen

- Videre forskning bør kartlegge sammenhengen mellom tidlige vansker med emosjonsregulering og senere utvikling av $\mathrm{AD} / \mathrm{HD}$-symptomer 


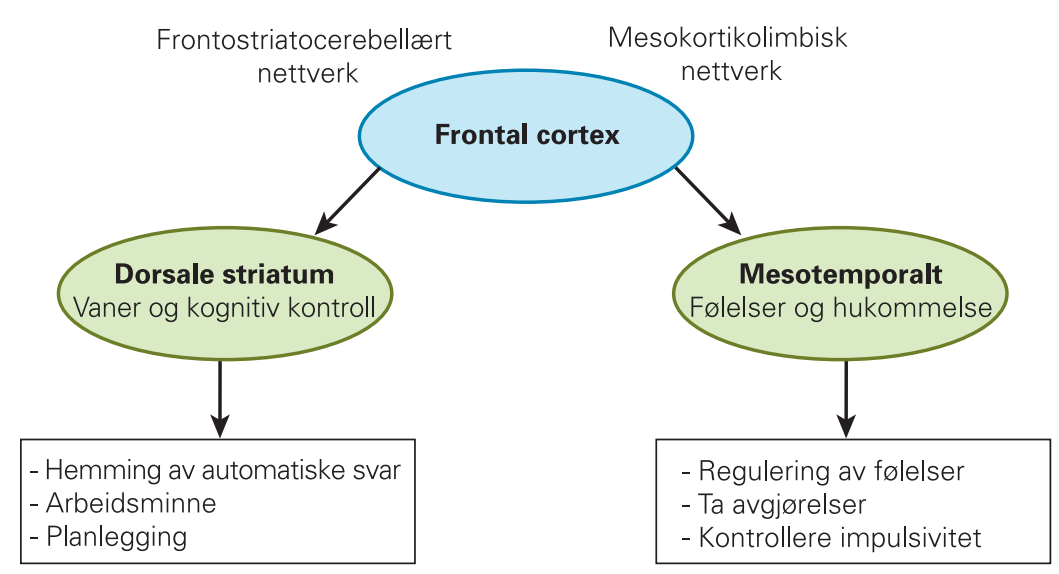

Figur 1 Oversikt over de to nettverkene som medierer henholdsvis kognitiv og emosjonell/motivasjonell kontroll

blemene kan tilsynelatende være et resultat av høy komorbiditet mellom AD/HD og angst (25\%) og depresjon (9-38\%) (10). Det er imidlertid sannsynlig at det finnes undergrupper av barn med $\mathrm{AD} / \mathrm{HD}$ uten komorbiditet som har problemer med emosjonsregulering og affektiv labilitet, mens en annen undergruppe kan ha unormalt lite angst og dermed være i risiko for å utvikle antisosial atferd (9).

Opptil $65 \%$ av alle som hadde $\mathrm{AD} / \mathrm{HD}$ som barn har fremdeles symptomer som voksne (11). Symptomprofilen hos voksne er mindre preget av hyperaktivitet og mer av oppmerksomhetsvansker og impulsivitet. Det er også vanlig for voksne pasienter å slite med angst, depresjon, emosjonelle problemer og rusmisbruk (12). Emosjonell dysregulering har vært vist hos $32 \%$ av voksne med AD/HD som ikke har annen komorbiditet (13). Det er et viktig spørsmål om graden av emosjonelle problemer pasientene har som barn kan være med på å forutsi mengden av slike tilleggsproblemer eller sykdomspersistens i voksen alder (14). I så fall er det viktig å identifisere disse pasientene

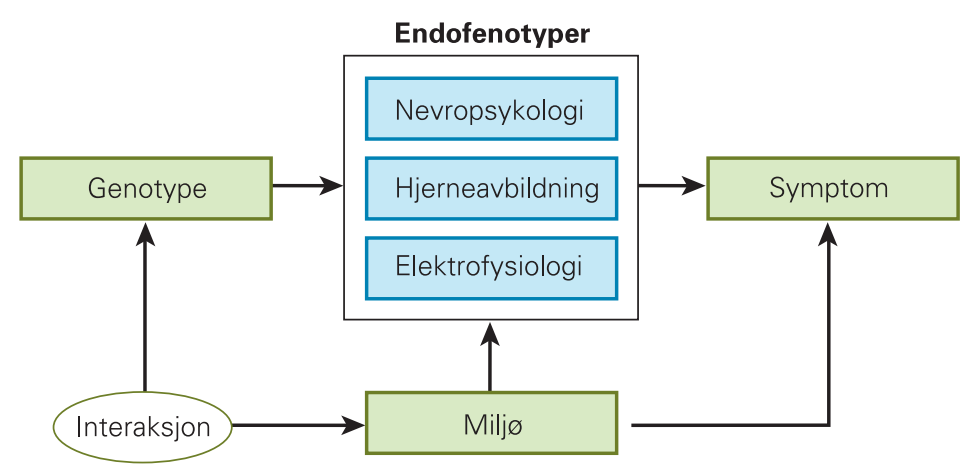

Figur 2 Endofenotyper er egenskaperi hjernen eller ved atferden som er bindeledd mellom genotype og fenotype. De kan måles ved f.eks. nevropsykologiske tester, hjerneavbildning eller elektrofysiologiske tester. Det er mange forskjellige genotyper og miljøfaktorer som kan interagere og påvirke symptomprofilen slik at man kan forebygge fremtidige tilleggsproblemer. En bedre beskrivelse av fenomenet gjennom å bruke endofenotyper som måler slikt er derfor svært nyttig (3).

\section{Genetikk}

Genetiske studier på $\mathrm{AD} / \mathrm{HD}$ har vist at det er omtrent $80 \%$ arvelighet (15). Kartlegging av kandidatgener har hittil vært vanskelig, da det ofte ikke har vært mulig å verifisere funnene $\mathrm{i}$ uavhengige utvalg. Resultatene kan tyde på at arvelighetsbildet er en komplisert sammensetning av mange gener som til sammen utgjør en genetisk sårbarhet for/ ev. beskyttelse mot å utvikle AD/HD.

Nevrotransmitterne dopamin og serotonin og deres metabolisme ser ut til å spille en viktig rolle når det gjelder impulsivitet og belønningsmekanismer. Genetiske og farmakologiske studier tyder på at serotonin særlig er involvert $\mathrm{i}$ de affektive aspektene ved impulsivitet (16). Nylig fant man i en stor studie med voksne at gener som koder for enzymer som er involvert i serotoninbiosyntesen, er assosiert med AD/HD (17). Dopaminreseptorer antas å spille en viktig rolle i $\mathrm{AD} / \mathrm{HD}$, spesielt resep- torene D4, D1 og D2. D2-reseptoren er assosiert med belønningsmekanismer (7).

\section{Endofenotyper}

Bruk av endofenotyper kan være en tilnærming til det å identifisere genene som ligger bak tilbøyeligheten til utvikling av AD/HD. En gruppeinndeling etter karakteristika funnet ved måling av endofenotyper vil gi mer homogene grupper og dermed sannsynligvis mer spesifikke resultater ved genetisk kartlegging. Dette kan muligens også bidra til utvikling av nye terapiformer og smalere terapiindikasjoner. Her presenteres derfor et utvalg endofenotyper ved $\mathrm{AD} / \mathrm{HD}$ innen nevropsykologi, hjerneavbildning og elektrofysiologi, med vekt på emosjonsregulering og motivasjon (fig 2).

\section{Nevropsykologi}

Innen $\mathrm{AD} / \mathrm{HD}$ er det beskrevet en rekke nevropsykologiske endofenotyper, f.eks. variabel reaksjonstid, vansker med å vedlikeholde konsentrasjonen, responsundertrykking, visuelt arbeidsminne, tidsprosessering, motorisk kontroll, aktivering og motivasjon $(18,19)$. En dypere forståelse av dopaminkretsløpet fra dyrestudier og farmakologiske studier støtter modellen om motivasjonelle vansker som årsak til symptomer på AD/HD. Dette er en av de to parallelle årsaksmodellene som inkluderes i den nyere modellen (dual pathway). Motivasjonelle vansker kan skyldes en dysfunksjon i modulerende dopaminerge responser på forsterkere (20). Resultatet av denne dysfunksjonen er en unormalt bratt forsinkelse-belønnings-gradient. En slik bratt gradient innebærer at belønninger får lav forsterkningseffekt hos barn med AD/HD hvis de ligger langt frem i tid, mens umiddelbare forsterkninger har høy effekt. Det er vist at barn med AD/HD har utbytte av hyppige og kraftige forsterkere som normaliserer atferden både på skolen og hjemme (21).

Det er også vist at pasienter med AD/HD har problemer med å identifisere emosjonelle uttrykk, spesielt gjelder det negative ansiktsuttrykk som frykt, sinne og tristhet (22). Dette kan komme av en primær svikt i evnen til å kode emosjonelle signaler.

\section{Hjerneavbildning}

Hjerneavbildningsteknikker, spesielt magnetisk resonanstomografi (MR), er de siste tiårene blitt brukt til kartlegging av nevrobiologiske faktorer ved nevropsykiatriske lidelser hos barn. Endret hjernestruktur og/eller -funksjon er blitt beskrevet $i$ avgrensede områder av hjernen hos personer med $\mathrm{AD} /$ HD. Avvik fra det man finner hos friske kontrollpersoner sier imidlertid ikke noe om hvorvidt endringen er årsak til symptomene, om det er en kompensatorisk mekanisme eller om den har direkte sammenheng med sykdommen. Funn fra slike studier har ennå ikke plass i diagnostiseringen.

Ut fra hjerneavbildning er det mye som 
tyder på at frontostriatale baner, som medierer høyere kognitive funksjoner, er underaktiverte og dysfunksjonelle hos personer med $\mathrm{AD} / \mathrm{HD}$. Dette avviket fører til at det under utviklingen i barne- og ungdomsårene rekrutteres andre regioner for å kompensere (18). I undersøkelser der man har brukt funksjonell MR ved oppgaver som krever hemming av automatisk atferd, er det påvist at avviket $i$ aktiveringsmønstre hos pasienter med $\mathrm{AD} /$ HD og pasienter med atferdsforstyrrelse skiller seg fra hverandre. Dette viser dermed spesifisiteten av endofenotyper (23).

Det finnes derimot få studier der man har tatt for seg hjerneregionene som medierer emosjonell og motivasjonell kontroll hos pasienter med AD/HD. Motivasjonell kontroll medieres av mesokortikolimbiske baner og overlapper med hjernens belønningssystem, som inkluderer orbitofrontal cortex, fremre del av gyrus cinguli, ventrale striatum/nucleus accumbens og det limbiske system (gyrus cinguli, septumkjernene, hippocampusformasjonen og amygdala). Studier med funksjonell MR har vist redusert aktivering av ventrale striatum/nucleus accumbens hos mennesker med AD/HD sammenliknet med friske kontrollpersoner under oppgaver hvor forsøkspersonene forventet belønning, både umiddelbar belønning og forsinket belønning $(24,25)$. I en annen studie fant man økt aktivering i dorsale nucleus caudatus og amygdala ved forsinket belønning samt at denne økte aktiveringen korrelerte positivt med graden av symptomer på hyperaktivitet og impulsivitet (25). Disse resultatene støtter teorien om at et hypofunksjonelt belønningssystem er involvert i symptomer på hyperaktivitet og impulsivitet.

Emosjonsreguleringen er avhengig av samspill mellom orbitofrontal cortex, ventromedial prefrontal cortex, fremre del av gyrus cinguli, amygdala, hippocampus og ventrale striatum/nucleus accumbens. I en studie ble det funnet at flere av underregionene i amygdala var mindre hos dem med $\mathrm{AD} / \mathrm{HD}$ enn hos kontrollpersoner, og interregionale korrelasjoner tydet på at det forelå en forstyrret forbindelse mellom orbitofrontal cortex og amygdala hos barn med AD/ HD. Disse resultatene indikerer at det limbiske system er involvert i patofysiologien ved sykdommen (26) (fig 3).

\section{Elektrofysiologi}

Med EEG kan man også studere hendelsesrelaterte potensialer/ERP (event-related potentials), som er elektrofysiologiske responser på interne eller eksterne stimuli. Hos barn med $\mathrm{AD} / \mathrm{HD}$ er det vist avvik ved slike undersøkelser (27).

Hos disse barna er det typisk endringer i hendelsesrelaterte potensialer under tester som involverer belønning eller emosjonell prosessering (22). I en studie ble barn med $\mathrm{AD} / \mathrm{HD}$ og kontrollbarn belønnet midtveis i testingen og etterpå. Etter første belønning ble amplituden til en belønningsrelatert kompo- nent av et hendelsesrelatert potensial redusert for kontrollbarna, mens den økte hos dem med AD/HD (28). Dette indikerer at barn med $\mathrm{AD} / \mathrm{HD}$ er uvanlig sensitive for egenskapene ved belønning, noe som tidligere er vist for situasjoner hvor de kan tape gevinst (29). Resultater fra sistnevnte studie tyder på at også videre prosessering, som affektiv evaluering og vurdering av senere konsekvenser, kan være endret. I en studie der man undersøkte hendelsesrelaterte potensialer hos voksne med $\mathrm{AD} / \mathrm{HD}$ ble det vist at disse er mindre reaktive overfor emosjonelt positivt fargede stimuli enn friske kontrollpersoner (30).

\section{Miljø}

$\mathrm{Vi}$ vet om en rekke miljøfaktorer som preger utvikling og alvorlighetsgrad av sykdommen, men det er gjort lite forskning spesifikt på utvikling av emosjonsreguleringen hos barn med AD/HD. Hos friske barn er tidlig samspill med omsorgspersonene viktig for utviklingen av trygg tilknytning, som igjen danner grunnlaget for adekvat emosjonsregulering $(9,31)$.

Konflikter i familien/foreldrenes ekteskap $(18,32)$, psykopatologiske symptomer og tidligere symptomer på $\mathrm{AD} / \mathrm{HD}$ hos foreldrene, antisosial $/ \mathrm{kriminell}$ atferd og rusmisbruk (32) spiller en avgjørende rolle for deres generelle fungering, og det er vist at disse elementene er av betydning for utvikling av $\mathrm{AD} /$ HD hos barnet. Man kan tenke seg at disse faktorene indikerer manglende stabilitet hos foreldrene, slik at de ikke kan romme barnets følelser. For flere av disse miljøfaktorene er det usikkert om det dreier seg om korrelasjoner eller kausale sammenhenger. Det er også vanskelig å få klarhet i om faktorer som foreldrenes atferd og psykopatologiske symptomer påvirker sårbarheten for $\mathrm{AD} / \mathrm{HD}$ gjennom genene eller som miljøfaktorer.

\section{Forebygging og behandling}

Hvis foreldrene har $\mathrm{AD} / \mathrm{HD}$, er det en genetisk tilbøyelighet hos barnet til å utvikle sykdommen. I tillegg kan inkonsekvent, impulsiv og uorganisert oppdragelse øke sannsynligheten for at barnet utvikler AD/HD-symptomer (20). Konsekvent og organisert oppdragelse kan på den annen side virke som en beskyttende faktor mot å utvikle sykdommen og fremme barnets evne til å regulere følelsene sine. Det er laget et videobasert veiledningsprogram til hjelp for foreldre med barn i alderen 2-8 år som har/risikerer å utvikle atferdsvansker (33). Dette har vist seg å forebygge og redusere atferdsproblemer (34).

Det er godt dokumentert at sentralstimulerende medisiner reduserer hovedsymptomene på $\mathrm{AD} / \mathrm{HD}$, men den direkte effekten på emosjonsreguleringen hos barn er ikke undersøkt (22). Likevel vil en generell bedring av selvreguleringen som følge av slik medisinering sannsynligvis også hjelpe på denne type problemer. Det er også vist at metylfenidat motvirker svekket emosjonsgjenkjennelse (22) og normaliserer belønningsprosesseringen gjennom nedregulering av den hypersensitive orbitofrontale aktiveringen (35) hos pasienter med AD/HD. Når det gjelder det ikke-sentralstimulerende medikamentet atomoksetin, er det $\mathrm{i}$ en studie med voksne med $\mathrm{AD} / \mathrm{HD}$ vist at medikamentet har like stor behandlingseffekt på emosjonell dysregulering som på hovedsymptomene (13).

\section{Konklusjon}

Nyere teorier og studier fremhever emosjonelle/motivasjonelle faktorers betydning for utvikling av AD/HD. Emosjonell dysregulering ser ut til å være et utbredt og funksjonsnedsettende aspekt ved sykdommen. Et hypofunksjonelt dopaminsystem, som gir motivasjonelle vansker og endret respons på belønning, kan være en viktig årsaksfaktor i utvikling av AD/HD. Det er behov for mer forskning på dette feltet, og bruk av endofenotyper ved inndeling av undergrupper kan gi mer robuste resultater. Vi har for lite kunnskap om utvikling av emosjonelle og motivasjonelle problemer blant personer med AD/HD i et livstidsperspektiv, derfor er

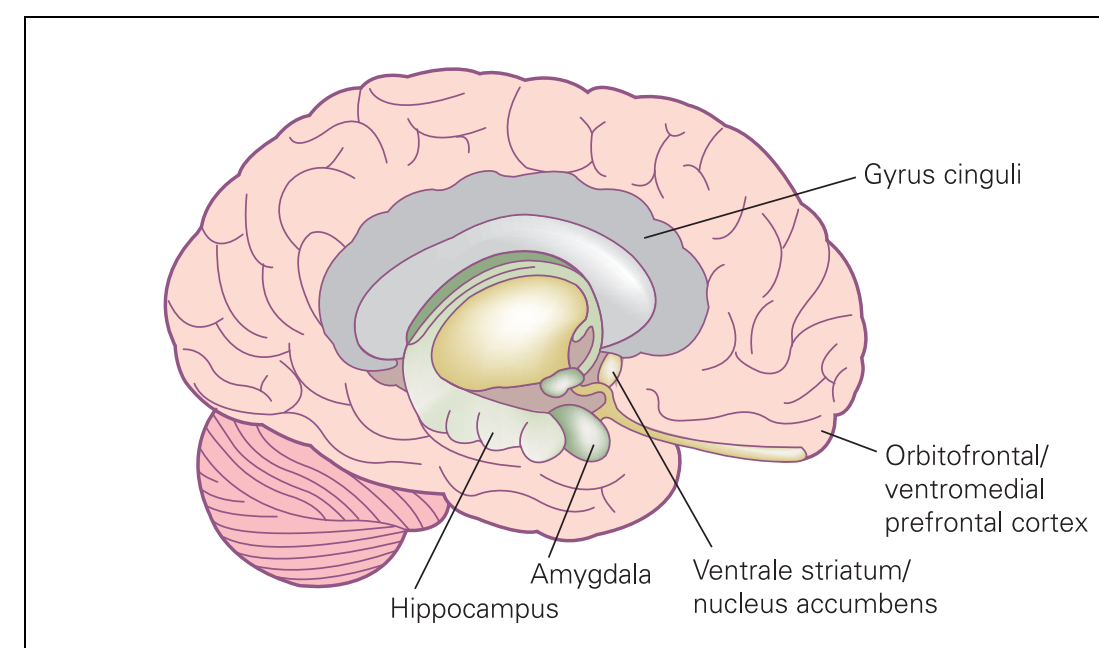

Figur 3 Oversikt over nøkkelområder i hjernen som er involvert i regulering av følelsene 
longitudinelle studier spesielt viktige. Med mer forskning kan vi forhåpentligvis med tiden forstå den urolige gutten bedre og utvikle mer spesialiserte terapiformer.

Oppgitte interessekonflikter: Ingen

Vi takker for støtte fra Regionsenter for barn og unges psykiske helse - Vest, Uni Research (Marie Farstad Høvik), Norges forskningsråd (Marie Farstad Høvik og Kerstin J. Plessen), Samarbeidsorganet Helse-Vest (MoodNet) og Nasjonalt Kompetansenettverk for ADHD (Kerstin J. Plessen).

\section{Litteratur}

1. Sonuga-Barke EJ. The dual pathway model of AD/ HD: an elaboration of neuro-developmental characteristics. Neurosci Biobehav Rev 2003; 27: 593-604.

2. Martel MM. Research review: a new perspective on attention-deficit/hyperactivity disorder: emotion dysregulation and trait models. J Child Psychol Psychiatry 2009; 50: 1042-51.

3. Gottesman II, Gould TD. The endophenotype concept in psychiatry: etymology and strategic intentions. Am J Psychiatry 2003; 160: 636-45.

4. Polanczyk G, de Lima MS, Horta BL et al. The worldwide prevalence of ADHD: a systematic review and metaregression analysis. Am J Psychiatry 2007; 164: 942-8

5. American Psychiatric Association. Diagnostic and statistical manual of mental disorders: DSM-IV. 4 utg. Washington, DC: American Psychiatric Association, 1994.

6. Barkley RA. Behavioral inhibition, sustained attention, and executive functions: constructing a unifying theory of ADHD. Psychol Bull 1997; 121: 65-94.

7. Sonuga-Barke EJ. Psychological heterogeneity in AD/HD-a dual pathway model of behaviour and cognition. Behav Brain Res 2002; 130: 29-36.

8. Sobanski E, Banaschewski T, Asherson P et al. Emotional lability in children and adolescents with attention deficit/hyperactivity disorder (ADHD) clinical correlates and familial prevalence. J Child Psychol Psychiatry 2010; 51: 915-23.

9. Nigg JT, Casey BJ. An integrative theory of attention-deficit/ hyperactivity disorder based on the cognitive and affective neurosciences. Dev Psychopathol 2005; 17: 785-806.

10. Hechtman L. Assessment and diagnosis of attention-deficit/hyperactivity disorder. Child Adolesc Psychiatr Clin N Am 2000; 9: 481-98.
11. Faraone SV, Biederman J, Mick E. The agedependent decline of attention deficit hyperactivity disorder: a meta-analysis of follow-up studies. Psychol Med 2006; 36: 159-65.

12. Halmøy A, Fasmer OB, Gillberg $C$ et al. Occupational outcome in adult ADHD: impact of symptom profile, comorbid psychiatric problems, and treatment: a cross-sectional study of 414 clinically diagnosed adult ADHD patients. J Atten Disord 2009; 13: $175-87$

13. Reimherr FW, Marchant BK, Strong RE et al. Emo tional dysregulation in adult ADHD and response to atomoxetine. Biol Psychiatry 2005; 58: 125-31.

14. Barkley RA, Fischer M. The unique contribution of emotional impulsiveness to impairment in major life activities in hyperactive children as adults. J Am Acad Child Adolesc Psychiatry 2010; 49: 503-13.

15. Schubiner H, Katragadda S. Overview of epidemiology, clinical features, genetics, neurobiology, and prognosis of adolescent attention-deficit/ hyperactivity disorder. Adolesc Med State Art Rev 2008; 19: 209-15

16. Chamberlain SR, Müller U, Robbins TW et al. Neuropharmacological modulation of cognition. Curr Opin Neurol 2006; 19: 607-12.

17. Haavik J, Blau N, Thöny B. Mutations in human monoamine-related neurotransmitter pathway genes. Hum Mutat 2008: 29: 891-902.

18. Roth RM, Saykin AJ. Executive dysfunction in attention-deficit/hyperactivity disorder: cognitive and neuroimaging findings. Psychiatr Clin North Am 2004; 27: 83-96.

19. Nigg JT. Neuropsychologic theory and findings in attention-deficit/hyperactivity disorder: the state of the field and salient challenges for the coming decade. Biol Psychiatry 2005; 57: 1424-35.

20. Sagvolden T, Johansen EB, Aase $\mathrm{H}$ et al. A dynamic developmental theory of attention-deficit/hyperactivity disorder (ADHD) predominantly hyperactive/impulsive and combined subtypes. Behav Brain Sci 2005; 28: 397-419.

21. Luman M, Oosterlaan J Sergeant JA. The impact of reinforcement contingencies on AD/HD: a review and theoretical appraisal. Clin Psychol Rev 2005; 25: 183-213.

22. Williams LM, Hermens DF Palmer D et al. Misinterpreting emotional expressions in attention-deficit/hyperactivity disorder: evidence for a neural marker and stimulant effects. Biol Psychiatry 2008; 63: 917-26.

23. Rubia K, Halari R, Smith AB et al. Shared and disorder-specific prefrontal abnormalities in boys with pure attention-deficit/hyperactivity disorder compared to boys with pure CD during interference inhibition and attention allocation. J Child Psychol Psychiatry 2009; 50: 669-78.
24. Scheres A, Milham MP. Knutson B et al. Ventral striatal hyporesponsiveness during reward anticipation in attention-deficit/hyperactivity disorder. Biol Psychiatry 2007; 61: 720-4.

25. Plichta MM, Vasic N. Wolf RC et al. Neural hyporesponsiveness and hyperresponsiveness during immediate and delayed reward processing in adult attention-deficit/hyperactivity disorder. Biol Psychiatry 2009; 65: 7-14

26. Plessen KJ, Bansal R, Zhu H et al. Hippocampus and amygdala morphology in attention-deficit/ hyperactivity disorder. Arch Gen Psychiatry 2006; 63: 795-807

27. Barry RJ, Johnstone SJ, Clarke AR. A review of electrophysiology in attention-deficit/hyperactivity disorder: II. Event-related potentials. Clin Neurophysiol 2003; 114: 184-98.

28. Holroyd CB, Baker TE, Kerns KA et al. Electrophysiological evidence of atypical motivation and reward processing in children with attention-deficit hyperactivity disorder. Neuropsychologia 2008; 46: $2234-42$

29. van Meel CS, Oosterlaan J, Heslenfeld DJ et al. Telling good from bad news: ADHD differentially affects processing of positive and negative feedback during guessing. Neuropsychologia 2005; 43 $1946-54$

30. Herrmann MJ, Schreppel T, Biehl SC et al. Emotional deficits in adult ADHD patients: an ERP study. Soc Cogn Affect Neurosci 2009; 4: 340-5

31. Bell MA, Deater-Deckard K. Biological systems and the development of self-regulation: integrating behavior, genetics, and psychophysiology. J Dev Behav Pediatr 2007; 28: 409-20.

32. Furman L. What is attention-deficit hyperactivity disorder (ADHD)? J Child Neurol 2005; 20: 994-1002.

33. Webster-Stratton $\mathrm{C}$. De utrolige årene: en veiledning i problemløsning for foreldre med barn i alderen 2-8 år. Oslo: Gyldendal Akademisk, 2007.

34. Barlow J. The Webster Stratton «Incredible Years» parent training programme reduces conduct problems in children. Evid Based Ment Health 2007; 10: 86

35. Rubia K, Halari R, Cubillo A et al. Methylphenidate normalises activation and functional connectivity deficits in attention and motivation networks in medication-naïve children with ADHD during a rewarded continuous performance task. Neuropharmacology 2009; 57: 640-52.

Manuskriptet ble mottatt 30.1. 2010 og godkjent 27.7. 2010. Medisinsk redaktør Are Brean. 